\title{
HUBUNGAN ANTARA RASIO NEUTROFIL-LIMFOSIT (RNL) DAN RASIO PLATELET-LIMFOSIT (RPL) DENGAN KADAR RNA VHC PADA PASIEN HEPATITIS C KRONIK
}

\author{
Syifa Mustika ${ }^{* \varpi}$, Kenty Wantri Anita ${ }^{* *}$, Nur Estu Wijayanti Saputri ${ }^{* * *}$ \\ Abstrak
}

\begin{abstract}
Hepatitis C merupakan penyakit inflamasi pada hati yang disebabkan oleh virus hepatitis C. Pada pasien yang terinfeksi hepatitis $\mathrm{C}$ akut $(\mathrm{HCA})$ akan sembuh tanpa memerlukan pengobatan, tetapi sebagian besar kasus HCA akan menjadi hepatitis C kronik (HCK) dan memerlukan pengobatan. Menurut WHO, sekitar 185 juta orang telah terinfeksi dan 350.000 jiwa setiap tahunnya meninggal karena hepatitis $\mathrm{C}$. Di Indonesia, 4-5 juta jiwa terinfeksi hepatitis C dan sekitar 80\% akan menjadi HCK, 10-20\% dapat memburuk menjadi sirosis hati dan $1-5 \%$ per tahun meninggal. Rasio neutrophil-limfosit (RNL) dan rasio platelet-limfosit (RPL) dapat digunakan untuk memperkirakan respons terapi mencapai target sustained virological response (SVR). Pemeriksaan ini relatif murah, cepat dan mudah diakses. Penelitian ini bertujuan untuk mengetahui hubungan antara RNL dan RPL dengan kadar ribonucleic acid virus hepatitis C (RNA VHC) pada pasien HCK yang mendapatkan terapi di RS. Dr. Saiful Anwar Malang. Desain penelitian mengggunakan crosssectional berdasar data rekam medik pasien HCK dan sirosis hati terkompensasi yang telah melakukan pemeriksaan RNA VHC dan darah lengkap sebelum dan sesudah mendapatkan terapi. Sampel dipilih sesuai kriteria inklusi dan eksklusi sampai memenuhi 38 sampel. Hasil menunjukkan ada perbedaan signifikan kadar RNA VHC sebelum dan sesudah mendapatkan terapi sebesar $-5,373$ dengan $p=0,000$, sedangkan pada RNL $(p=0,179)$ dan RPL $(p=0,473)$ tidak ada perbedaan signifikan. Uji hubungan nilai RNL dengan kadar RNA VHC $(p=0,723)$ maupun RPL dengan kadar RNA VHC $(p=0,382)$ tidak ada hubungan signifikan sebelum mendapatkan terapi. Kesimpulannya, tidak terdapat hubungan yang signifikan antara RNL dan RPL dengan kadar RNA pada pasien HCK sebelum mendapatkan terapi, tetapi terdapat perbedaan yang signifikan pada kadar RNA VHC sebelum dan sesudah mendapatkan terapi.
\end{abstract}

Kata kunci: HCK, RNA VHC, RNL, RPL.

\section{CORRELATION BETWEEN NEUTROFIL-LIMFOSIT RATIO (NLR) AND PLATELET-LIMFOSIT (PLR) WITH HCV RNA LEVELS IN PATIENTS OF CHRONIC HEPATITIS C}

\begin{abstract}
Hepatitis $C$ is an inflammatory disease of the liver caused by the hepatitis $C$ virus. Patients infected with acute hepatitis $\mathrm{C}(\mathrm{AHC})$ will heal spontaneously without requiring treatment but the majority of $\mathrm{AHC}$ patients will become chronic hepatitis $\mathrm{C}(\mathrm{CHC})$ and require treatment. WHO said around 185 million people have been infected and 350,000 people die each year from hepatitis $C$. In Indonesia, 4-5 million people are infected with hepatitis $\mathrm{C}$ and around $80 \%$ will become $\mathrm{CHC}, 10-20 \%$ can worsen into liver cirrhosis and $1-5 \%$ per year died. Neutrophil-lymphocyte ratio (NLR) and platelet-lymphocyte ratio (PLR) can be used to estimate the therapeutic response to achieving the sustained virological response (SVR) target where this examination is relatively inexpensive, fast and easily accessible. This study aims to determine the relationship between NLR and PLR with hepatitis C virus ribonucleic acid (HCV RNA) levels in CHC patients receiving therapy at Dr. Saiful Anwar Public Hospital Malang. This was a cross-sectional study based on the medical record data of $\mathrm{CHC}$ patients and compensated liver cirrhosis who have take HCV RNA and complete blood examinations before and after receiving therapy. Samples were selected according to inclusion and exclusion criteria until they met 38 samples. The results showed that there was a significant difference in HCV RNA levels before and after receiving therapy of -5.373 with $p=0.000$ whereas in NLR $(p=0.179)$ and PLR $(p=0.473)$ there were no significant differences. There is no significant relationship between NLR values with HCV RNA levels $(p=0.723)$ and PLR with HCV RNA levels $(p=0.382)$ before receiving therapy. It can be concluded that there is no significant relationship between RNL and RPL with RNA levels in HCK patients before receiving therapy but there are significant differences in HCV RNA levels before and after receiving therapy.
\end{abstract}

Keywords: AHC, HCV RNA, NLR, PLR.

* Departemen IImu Penyakit Dalam, Fakultas Kedokteran, Universitas Brawijaya

" Departemen Patologi Anatomi, Fakultas Kedokteran, Universitas Brawijaya

*** Jurusan Pendidikan Dokter (S1), Fakultas Kedokteran, Universitas Brawijaya

凶Email: drtika78@gmail.com 


\section{Pendahuluan}

Hepatitis $C$ merupakan penyakit inflamasi pada hati yang disebabkan oleh virus hepatitis C (VHC). Virus ini termasuk ke dalam golongan virus ribonucleic acid (RNA) dari genus Hepacivirus dan famili Flaviviridae. ${ }^{1}$ Hepatitis $C$ dibagi menjadi 2 fase berdasarkan waktu yakni hepatitis $\mathrm{C}$ akut $(\mathrm{HCA})$ dan hepatitis $C$ kronik (HCK). Seorang yang terinfeksi HCA sering kali sembuh spontan tetapi sebagian besar akan memasuki fase kronik menjadi HCK akibat tubuh tidak mampu mengatasi infeksi dan membutuhkan terapi pengobatan. ${ }^{2}$

Infeksi HCK didefinisikan sebagai infeksi dengan VHC bertahan lebih dari enam bulan. ${ }^{1}$ Tanda dan gejala pada HCK antara lain terdapat asites (akumulasi cairan di perut), memar dan kecenderungan perdarahan, varises (pembuluh darah yang membesar, terutama di lambung dan esofagus), ikterik atau jaundice, dan sindrom gangguan kognitif yang dikenal sebagai ensefalopati hepatik. ${ }^{3}$

Penegakkan diagnosis pada penyakit hepatitis $C$ khususnya pada HCK dapat dilakukan dengan anamnesis, pemeriksaan fisik, dan pemeriksaan penunjang. Pemeiksaan penunjang pada HCK dapat ditegakkan apabila anti-VHC dan RNA VHC tetap terdeteksi lebih dari 6 bulan sejak terinfeksi disertai dengan gejala-gejala penyakit hati kronik.

Pemeriksaan anti-VHC dengan menggunakan teknik Enzyme Linked Immunosorbent Assay (ELISA) merupakan pilihan utama untuk mendeteksi infeksi HCA maupun HCK. ${ }^{4}$ Apabila diduga suatu infeksi hepatitis $\mathrm{C}$ dan didapatkan anti-VHC negatif (-), maka dilanjutkan dengan pemeriksaan RNA VHC dengan menggunakan reversed-transcription polymerase chain reaction (RT$\mathrm{PCR}$ ) untuk memastikan diagnosis secara akurat. ${ }^{2}$ Pemeriksaan RNA VHC dengan muatan virus RNA VHC dinyatakan dalam satuan $\mathrm{IU} / \mathrm{mL}$ digunakan untuk konfirmasi diagnosis pada pasien dengan anti-VHC positif. ${ }^{4}$

Seiring dengan perkembangan, muncul terapi yang sampai saat ini digunakan pada HCK adalah penemuan agen direct acting antiviral (DAA). Terapi pengobatan DAA yang tersedia di Indonesia saat ini adalah sofosbuvir, ledipasvir/sofosbuvir, simeprevir, dan daclatasvir, sehingga terapi pilihan HCK saat ini dapat dilakukan dengan strategi nondual therapy (kombinasi DAA dengan atau tanpa regimen Peg-IFNa). ${ }^{2,6}$

Pada VHC untuk mengukur keberhasilan respons terapi terhadap suatu pengobatan dapat diketahui dengan target suistainable virological response (SVR). Namun, kesadaran akan akses pengecekan dan pengobatan untuk memprediksi keberhasilan terapi pada HCK masih rendah. ${ }^{5} \mathrm{Hal}$ ini karena pemeriksaan RNA VHC terbilang sangat mahal dan tidak semua fasilitas kesehatan di Indonesia mempunyai pemeriksaan tersebut serta tidak semua pasien yang telah mendapatkan terapi dapat melakukan pemeriksaan tersebut. Maka diperlukan pemeriksaan penunjang lain yang dapat menjangkau semua pasien, tersedia di semua fasilitas kesehatan di Indonesia dan dapat memonitor hasil terapi pada pasien HCK dengan baik yakni dengan menggunakan pemeriksaan darah lengkap dengan parameter indikator neutrofil, limfosit dan trombosit. Rasio neutrofil-limfosit (RNL) merupakan perhitungan perbandingan jumlah neutrofil absolut dibagi dengan jumlah limfosit absolut yang dapat digunakan sebagai parameter untuk menentukan hilangnya status inflamasi yang berat pada keberhasilan respons terapi HCK.7,8. Rasio plateletlimfosit (RPL) merupakan perhitungan perbandingan jumlah trombosit dibagi dengan jumlah limfosit absolut yang dapat digunakan sebagai prediktor untuk menentukan ada tidaknya progresi penyakit hati lanjut pada keberhasilan respons terapi HCK ${ }^{9}$ 
Berdasarkan uraian di atas, maka peneliti ingin mengetahui peran dari nilai RNL dan RPL dalam mengukur kadar RNA VHC pada pasien HCK sebelum dan sesudah mendapatkan terapi.

\section{Bahan dan Metode}

Penelitian ini menggunakan desain penelitian observasional analitik dengan pendekatan cross-sectional study berupa analisis data yang didapatkan dari rekam medik semua pasien HCK yang dirawat di Rumah Sakit Dr. Saiful Anwar Malang mulai periode Januari 2014 - Februari 2019.

Populasi penelitian ini adalah pasien HCK yang telah dilakukan pemeriksaan darah lengkap dan telah mendapatkan terapi di Rumah Sakit Dr. Saiful Anwar Malang periode Januari 2014-Februari 2019. Variabel dalam penelitian ini menggunakan data nilai RNL, RPL, dan kadar RNA VHC pada pasien HCK sebelum dan sesudah mendapatkan terapi. Sampel diambil berdasarkan data sampel yang memenuhi kriteria inklusi dan eksklusi. Berdasarkan rumus sampel untuk uji hipotesis cross-sectional study diperlukan minimal 38 sampel. Kriteria inklusi meliputi pasien HCK dan sirosis hati terkompensasi usia 20 tahun ke atas yang telah melakukan kontrol pemeriksaan kadar RNA VHC dan pemeriksaan darah lengkap sebelum dan sesudah mendapatkan terapi, pasien yang mendapatkan terapi Peg-IFNa dan DAA. Kriteria eksklusi meliputi pasien HCK dan sirosis hati terkompensasi dengan koinfeksi penyakit lain seperti aterosklerosis, gagal jantung, CKD, HIV, VHB, kanker kolon dan sepsis serta pasien yang melakukan penghentian terapi sebelum waktunya.

Analisis data menggunakan program Statistical Package for Social Sciences (SPSS) melalui pengujian kenormalan data dilakukan menggunakan Kolmogorov Smirnov, dengan kriteria apabila nilai $p>0,05$ maka data tersebut dinyatakan normal. Pada penelitian ini menggunakan paired T-test untuk mengetahui adanya perbedaan antara kadar RNA VHC, nilai RNL dan nilai RPL pada pasien HCK dan Sirosis Hati terkompensasi sebelum dan sesudah mendapatkan terapi apabila data terdistribusi normal, sedangkan apabila tidak terdistribusi dengan normal dapat menggunakan uji Wilcoxon. Uji Korelasi Pearson untuk mengetahui adanya hubungan antara nilai RNL dan nilai RPL dengan kadar RNA VHC pada pasien HCK dan Sirosis Hati ter-kompensasi sebelum mendapatkan terapi apabila data terdistribusi normal, sedangkan apabila tidak terdistribusi dengan normal dapat menggunakan uji korelasi rank Spearman.

\section{Hasil}

Berdasarkan kriteria inklusi dan eksklusi didapatkan 38 sampel dengan karakteristik sampel atau subjek seperti yang ditampilkan pada Tabel 1.

Seluruh data nilai RNL, RPL, dan kadar RNA VHC pada pasien HCK dan sirosis hati terkompensasi sebelum dan sesudah mendapatkan terapi dianalisis secara deskriptif untuk mengetahui nilai minimum, maksimum, rata-rata (mean), dan standar deviasinya ditampikan pada Tabel 2. Uji Z dilakukan untuk mengetahui perbedaan kadar RNA VHC sebelum dan sesudah mendapatkan terapi, didapatkan nilai sebesar $-5.373(p=$ $0,000 ; p<0,05)$, sehingga dapat dikatakan bahwa terdapat perbedaan yang signifikan kadar RNA VHC pada pasien HCK dan sirosis hati terkompensasi sebelum dan sesudah mendapatkan terapi. Uji $\mathrm{T}$ dilakukan untuk mengetahui perbedaan nilai RNL sebelum dan sesudah mendapatkan terapi, didapatkan nilai sebesar 1,370 dengan nilai $p=0,179(p>0,05)$, sehingga dikatakan bahwa terdapat perbedaan yang signifikan antara nilai RNL pada pasien HCK dan sirosis hati terkompensasi sebelum dan sesudah mendapatkan terapi. 
Tabel 1. Karakteristik pasien HCK dan sirosis hati terkompensasi

\begin{tabular}{lcc}
\hline \multicolumn{1}{c}{ Variabel } & $\mathrm{n}$ & $\%$ \\
\hline Jenis Kelamin & 24 & 63 \\
Laki - laki & 14 & 37 \\
Perempuan & & \\
Usia (tahun) & 1 & 3 \\
20 - 29 & 5 & 13 \\
$30-39$ & 9 & 23 \\
40 - 49 & 7 & 18 \\
$50-59$ & 12 & 32 \\
$60-69$ & 3 & 8 \\
$70-79$ & 1 & 3 \\
$80-89$ & & \\
Regimen pengobatan & 13 & 34 \\
SOF + DAC & 1 & 3 \\
SOF + DAC + RBV & 1 & 3 \\
PEG IFNa + SOF + RBV & 19 & 50 \\
PEG IFNa-2b & 23 & 60 \\
SVR & & \\
SVR12 & 19 & 50 \\
SVR24 & 19 & \\
\hline
\end{tabular}

Tabel 2. Hasil analisis deskriptif

\begin{tabular}{|c|c|c|c|c|}
\hline Variabel & Minimum & Maximum & Mean & Standar Deviasi \\
\hline \multicolumn{5}{|l|}{ Sebelum terapi } \\
\hline $\mathrm{RNL}(/ \mu \mathrm{L})$ & 0,40 & 5,41 & 1,82 & 1,17 \\
\hline $\mathrm{RPL}(/ \mu \mathrm{L})$ & 26,25 & $1,52 \times 10^{6}$ & $2,15 \times 10^{5}$ & $4,3 \times 10^{5}$ \\
\hline RNA (IU/mL) & $3,3 \times 10^{2}$ & $1,18 \times 10^{7}$ & $1,01 \times 10^{6}$ & $2,3 \times 10^{6}$ \\
\hline \multicolumn{5}{|l|}{ Sesudah terapi } \\
\hline 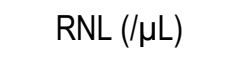 & 0,30 & 4,22 & 1,65 & 0,97 \\
\hline $\mathrm{RPL}(/ \mu \mathrm{L})$ & 16,91 & $6,8 \times 10^{5}$ & $8,27 \times 10^{4}$ & $1,7 \times 10^{5}$ \\
\hline RNA (IU/mL) & 0,00 & 0,00 & 0,00 & 0,00 \\
\hline
\end{tabular}


Uji Z dilakukan untuk mengetahui perbedaan nilai RPL pasien sebelum dan sesudah mendapatkan terapi didapatkan nilai sebesar $-0,718$ dengan nilai $p=0,473(p>0,05)$, sehingga dapat dikatakan tidak terdapat perbedaan yang signifikan pada nilai RPL pasien HCK dan sirosis hati terkompensasi sebelum dan sesudah mendapatkan terapi. Uji korelasi nilai RNL dengan kadar RNA VHC sebelum mendapatkan terapi, didapatkan nilai $p=$ 0,723 yang berarti tidak terdapat hubungan yang signifikan nilai RNL dengan kadar RNA VHC pasien HCK dan sirosis hati terkompensasi sebelum mendapatkan terapi. Koefisien korelasi didapatkan sebesar 0,059 yang menunjukkan ada hubungan yang positif (searah) dan sangat lemah. Uji korelasi nilai RPL dengan kadar RNA VHC sebelum mendapatkan terapi, didapatkan nilai $p=0,382$ yang dinyatakan tidak terdapat hubungan yang signifikan nilai RPL dengan kadar RNA VHC pasien HCK dan sirosis hati terkompensasi sebelum mendapatkan terapi. Koefisien korelasi didapatkan sebesar 0,146 yang dapat menunjukkan ada hubungan yang positif (searah) dan sangat lemah.

\section{Pembahasan}

Pada penelitian ini didapatkan pasien HCK dan sirosis hati terkompensasi sebelum mendapatkan terapi di Rumah Sakit Dr. Saiful Anwar Malang didominasi oleh laki-laki yaitu sebesar $63 \%$ dan sisanya adalah perempuan sebesar $37 \%$. Survei yang dilakukan oleh CDC pada tahun 2016 juga menunjukan bahwa pasien HCK didapatkan lebih banyak berjenis kelamin laki-laki daripada perempuan. Sebanyak 61,3\% laki-laki didiagnosa mengidap penyakit HCK di Amerika, lebih banyak daripada perempuan yaitu sebesar $38.1 \% .{ }^{9} \mathrm{Hal}$ ini dapat disebabkan oleh faktor risiko terinfeksi yang lebih besar pada laki-laki. Sa-lah satunya adalah mereka yang meng-gunakan narkoba suntik (penasun). Penasun memiliki risiko terkena infeksi HCK lebih tinggi dibandingkan dengan faktor lain. Hal ini karena penggunaan narkoba suntik secara bergantian lebih banyak menyalurkan penularan terutama melalui parenteral terha-dap cairan tubuh yang mengandung darah. ${ }^{9}$

Berdasarkan karakteristik data dasar sampel, didapatkan bahwa sebagian besar pasien HCK dan sirosis hati terkompensasi di Rumah Sakit Dr. Saiful Anwar Malang berusia 60-69 tahun yang berjumlah 12 orang (60\%). Hal ini berbeda dengan data Perhimpunan Peneliti Hati Indonesia pada tahun 2017 yang mendapatkan kelompok usia produktif 2029 tahun paling banyak mengidap HCK yaitu sebesar 30,94\%.2 Namun, data CDC menunjukkan bahwa di Amerika pada tahun 2016 sebagian besar pasien HCK berusia lebih dari 55 tahun yaitu sebanyak $38,1 \%$ dari 148.932 kasus. CDC melaporkan bahwa pasien HCK berusia lebih dari 55 tahun lebih banyak terdiagnosa daripada pasien yang usianya lebih muda karena mereka tidak menyadari bahwa tubuhnya telah terinfeksi VHC dan tidak menunjukkan gejala. Tanpa disadari mereka sudah memasuki fase HCK sehingga menyebabkan prognosis yang lebih buruk dan tingkat survival yang lebih pendek dibandingkan dengan pasien HCK yang usianya lebih muda. ${ }^{9}$

Penelitian ini menunjukkan bahwa ada perbedaan yang signifikan kadar RNA VHC pada pasien HCK sebelum dan sesudah mendapatkan terapi $(p=0,000)$. Diketahui nilai rata-rata kadar RNA VHC pada pasien HCK sebelum mendapatkan terapi lebih tinggi daripada sesudah mendapatkan terapi. Penelitian yang dilakukan oleh Loomba dkk (2010), menjelaskan bahwa kadar RNA VHC yang tinggi pada pasien hepatitis $\mathrm{C}$ sebelum mendapatkan terapi mengindikasikan adanya respons virologi yang menandai virus hepatitis $C$ telah masuk ke dalam tubuh, sedangkan kadar RNA VHC yang rendah pada pasien HCK sesudah mendapatkan terapi menunjukkan adanya pemulihan dan 
pembersihan virus. Pada penelitian tersebut terdapat 25 subjek pasien dengan hepatitis C. Rerata kadar RNA VHC sebelum mendapatkan terapi pada puncaknya yaitu $2,3 \times 10^{6} \mathrm{IU} / \mathrm{mL}$ daripada sesudah mendapatkan terapi sebesar $0.00 \mathrm{IU} / \mathrm{mL} .{ }^{10}$

Pada penelitian ini tidak terdapat perbedaan yang signifikan nilai RNL pada pasien HCK sebelum dan sesudah mendapatkan terapi $(p=0,179)$. Didapatkan rata-rata nilai RNL pada pasien HCK sebelum mendapatkan terapi yang bernilai lebih tinggi daripada sesudah mendapatkan terapi. Hasil penelitian Kuo (2014), menunjukkan bahwa RNL yang lebih tinggi merupakan prediktor independen yang buruk dari respons pengobatan sesudah men-dapatkan terapi dari SVR pada pasien HCK dengan genotip 2 tetapi tidak pada genotip 1 dan terjadi peningkatan replikasi VHC. ${ }^{8}$ Pada penelitian Lin dkk (2015), juga menyatakan bahwa RNL yang tinggi merupakan penanda adanya suatu inflamasi di dalam tubuh yang rentan terhadap suatu infeksi. ${ }^{11}$

Selain itu, didapatkan perbedaan nilai RPL yang tidak signifikan pada pasien HCK sebelum dan sesudah terapi $(p=0,473)$. Diketahui rata-rata nilai RPL pada pasien HCK sebelum terapi lebih tinggi daripada sesudah mendapatkan terapi. Berdasarkan penelitian Meng (2016), mengungkapkan bahwa RPL dari kelompok yang diberikan pengobatan secara signifikan lebih tinggi daripada yang tidak diobati dan menunjukkan adanya pembersihan VHC. ${ }^{12}$

Pada penelitian ini diketahui bahwa hubungan nilai RNL dengan kadar RNA VHC sebelum mendapatkan terapi tidak signifikan $(p=0,723)$ dengan nilai koefisien korelasi menunjukkan nilai positif sebesar 0,059 . Hal ini menunjukkan semakin tinggi nilai RNL maka kadar RNA VHC sebelum mendapatkan terapi juga semakin tinggi. Berdasarkan penelitian oleh Lin (2015), bahwa peningkatan RNL dapat mengindikasikan prognosis buruk dari chronic liver failure setelah dilaku-kan transplantasi hati. ${ }^{11}$ Pada penelitian lain juga melaporkan bahwa peningkatan RNL sebelum mendapatkan terapi dapat menunjukkan tanggapan virologi yang tidak diinginkan, tetapi dari nilai RNL tersebut tidak menunjukkan adanya hubungan yang signifikan terkait infeksi hepatitis C. ${ }^{9}$ Namun, ber-beda dengan penelitian Hayashi (2017) tentang hubungan antara perubahan pasca operasi nilai dari RLN pada orang dewasa dengan donor transplantasi hati (AA-LDLT) didapatkan peningkatan RLN yang lebih tinggi dapat digunakan sebagai prediktor perubahan inflamasi menjadi perburukan prognosis pada AA-LDLT.13

Penelitian ini menunjukkan bahwa hubungan nilai RPL dengan kadar RNA VHC sebelum mendapatkan terapi tidak signifikan $(p=0,382)$ dan nilai koefisien korelasi menunjukkan nilai positif sebesar 0,146 . Hal ini menunjukkan bahwa semakin tinggi nilai RPL, maka kadar RNA VHC sebelum mendapatkan terapi akan semakin tinggi. Penelitian He (2016), mengungkapkan bahwa nilai PLR pada sirosis hepatis secara signifikan lebih rendah daripada pasien HCK dengan probabilitas sirosis hepatis 0,015 $\pm 0,009$ dan HCK 0,022 $\pm 0,011.14$ Pada penelitian lain mendapatkan bahwa peningkatan RPL yang tinggi pada pasien HCK menunjukkan tanggapan virologi yang baik daripada pasien sirosis hepatis. ${ }^{9}$

Keterbatasan penelitian ini adalah pasien yang didapatkan tidak semua pasien HCK tetapi juga terdapat pasien sirosis hati terkompensasi. Faktor lain adalah pengobatan tiap pasien yang berbeda-beda, bahwa pengobatan tersebut dapat menun-jukkan adanya efek samping pengobatan yang berbeda-beda pada tiap pasien, contohnya terapi pengobatan Peg IFN- $\alpha$ yang dapat menimbulkan efek samping trombositopenia yang dapat mempengaruhi nilai dari RNL dan RPL. 


\section{Kesimpulan}

Dapat disimpulkan bahwa kadar RNA VHC pasien HCK dan sirosis hati terkompensasi sebelum dan sesudah mendapatkan terapi berbeda signifikan, sedangkan nilai RNL dan RPL tidak berbeda signifikan pada pasien HCK dan sirosis hati terkompensasi sebelum dan sesudah mendapatkan terapi. Juga, tidak terdapat hubungan yang signifikan antara RNL maupun RPL dengan kadar RNA VHC pada pasien HCK dan sirosis hati terkompensasi sebelum mendapatkan terapi.

\section{Daftar Pustaka}

1. Sulaiman AH. Hepatitis C. Dalam: Buku Ajar IImu Penyakit Hati. Sulaiman AH, Akbar NH, Lesmana AL, Noer SMH (Editor). Edisi Pertama Revisi. Jakarta: CV. Sagung Seto. 2012. HIm. 223-247.

2. Indonesian Association for the Study of the Liver. Perhimpunan Peneliti Hati Indonesia (PPHI). Konsensus Nasional Penatalaksanaan Hepatitis C di Indonesia. PPHI Ina ASL. 2017.

3. Revier L, Sowers MH. Viral Hepatitis Causes, Diagnosis, and Treatment. California Association for Medical Laboratory Technology (CAMLT). Distance Learning Course DL-004. 2015.

4. European Association for the Study of the Liver (EASL). Clinical Practice Guidelines: Management of Virus Hepatitis C Infection. J Hepatol. 2016; 60(2):392-420.

5. WHO. Guidelines for the Screening, Care and Treatment of Persons with Hepatitis C Infection. Geneva: WHO. 2014. Pp. 1121.

6. World Health Organization. Guidelines for the Care and Treatment of Persons Diagnosed with Chronic Virus Hepatitis C Infection. Geneva: WHO. 2018.

7. Forget $P$, Khalifa $C$, Defour PJ, Latinne $D$, Pel V, Kock DM. What is the Normal
Value of the Neutrophil-to-Lymphocyte Ratio?. BMC Res Notes. 2017; 10:12. doi: 10.1186/s13104-016-2335-5.

8. Kuo MT, Hu TH, Lu SN, Hung $\mathrm{CH}$, Wang $\mathrm{JH}$, Chen $\mathrm{CH}$, et al. Neutrophil-toLymphocyte Ratio as a Predictor of Response to Peginterferon plus Ribavirin The -rapy for Chronic Hepatitis C. Disease Mar-ker. 2014; 1-6. doi: 10.1155/ 2014/ 462958.

9. Centers for Disease Control and Prevention. Viral Hepatitis SurveillanceUnited States. Atlanta: US Department of Health and Human Services, Centers for Disease Control and Prevention. (Online). 2016. https://www.cdc.gov/hepatitis/ statistics/2016surveillance/index.htm.

10. Loomba R, Rivera MM, McBurney R, Park $Y$, Haynes-Williams $V$, Rehermann $B$, et al. The Natural History of Acute Hepatitis C: Clinical Presentation, Laboratory Findings, and Treatment Outcomes. Aliment Pharmacol Ther. 2011; 33(5):559-565. doi:10.1111/j.13652036.2010.04549.x.

11. Lin BY, Zhou L, Geng L, Zheng ZY, Jia JJ, Zhang J, et al. High NeutrophilLymphocyte Ratio Indicates Poor Prognosis for Acute-on-Chronic Liver Failure after Liver Transplantation. World J Gastroenterol. 2015; 21:3317-3324.

12. Meng $X$, Wei G, Chang Q, Peng R, Shi G, Zheng $P$, et al. The Platelet-toLymphocyte Ratio, Superior to the Neutrophil-to-Lymphocyte Ratio, Correlates with Virus Hepatitis C Infection. International J Infect Dis. 2016; 45:72-77.

13. Hayashi $H$, Takamura $H$, Ohbatake $Y$, Nakanuma S, Tajima H, Fushida S, et al. Postoperative Changes in Neutrophil-toLymphocyte Ratio and Platelet Count: A Simple Prognostic Predictor for Adult-toAdult Living Donor Liver Transplantation. Asian Journal of Surgery. 2017; 41(4): 341-348. 
14. He Q, Qin X, Li S, Li T, Xie L, et al. The Relationship between Inflammatory Marker Levels and Hepatitis C Virus Severity. Gastroenterology Research and Practice. 2016;1-5. doi:10.1155/2016/2978479.2016. 